\title{
Development of a nursing website for critical care regarding healthcare-associated infections
}

\author{
Desenvolvimento de website para enfermagem em cuidados críticos sobre infecção relacionada à assistência à saúde
}

Desarrollo de website de enfermería en cuidados críticos sobre infección relacionada a atención de salud

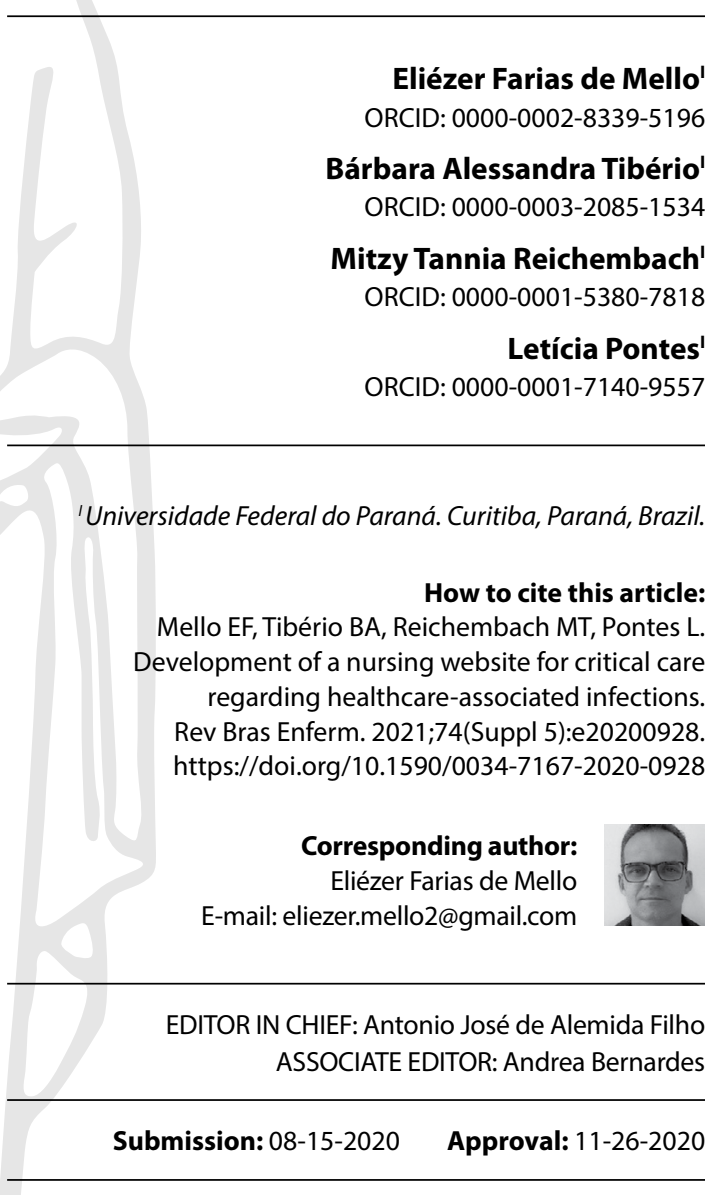

\begin{abstract}
Objective: to describe the development of a website about the main healthcare-associated infections and the respective bundles to prevent these diseases, oriented toward intensive care unit nursing. Methods: experience report describing the development of technological innovation by nurses, using computational tools and technological production methodological research and following the product development process. Results: nurses developed an educational website which can be accessed through computers, tablets, and smartphones at the electronic address irastis.com and focuses on healthcare-associated infections. Final considerations: digital technologies have contributed to fulfill demands in health care, research, and education. The developed website has the potential to support reduction in healthcareassociated infection rates, since it makes preventive measures for these infections available and refers users to publication environments that systematize the implementation of the bundles. Descriptors: Technology; Infections; Delivery of Health Care; Nursing; Critical Care.
\end{abstract}

\section{RESUMO}

Objetivo: descrever a construção de um website sobre as principais Infecções Relacionadas à Assistência à Saúde e os respectivos bundles para prevenção dessas infecções, para enfermagem de unidades de terapia intensiva. Método: relato de experiência sobre a construção de inovação tecnológica por enfermeiros, utilizando-se de ferramentas computacionais e da pesquisa metodológica de produção tecnológica, seguindo o Processo de Desenvolvimento de Produtos. Resultados: desenvolveu-se um website instrucional, que pode ser acessado por meio de computadores, tablets e smartphones, no endereço eletrônico "irastis.com", sobre Infecção Relacionada à Assistência à Saúde. Considerações finais: as tecnologias digitais têm contribuído para atender demandas da saúde na assistência, pesquisa e ensino. O website desenvolvido tem potencial para apoiar a redução dos índices de infecções relacionadas à assistência à saúde, na medida em que disponibiliza conhecimento sobre as medidas de prevenção dessas infecções e direciona o usuário a espaços de publicações que determinam a implementação dos bundles.

Descritores: Tecnologia; Infecções; Assistência à Saúde; Enfermagem; Cuidados Críticos.

\section{RESUMEN}

Objetivo: Describir la construcción de un website sobre las principales Infecciones Relacionadas a la Atención de Salud y los respectivos bundles de prevención de estas infecciones, para enfermería en unidades de terapia intensiva. Método: Relato de experiencia de construcción de innovación tecnológica por enfermeros, utilizando herramientas informáticas e investigación metodológica de producción tecnológica, siguiendo el Proceso de Desarrollo de Productos. Resultados: Se desarrolló el website instruccional, accesible mediante computadoras, tabletas y celulares, sobre Infección Relacionada a la Atención de Salud. Consideraciones finales: Las tecnologías digitales contribuyeron a atender demandas de salud en la atención, la investigación y la enseñanza. El website desarrollado tiene potencial para apoyar la reducción de índices de infecciones relacionadas a la atención de salud, además de poner a disposición medidas de prevención para tales infecciones y redirigir al usuario hacia espacios de publicaciones que determinan la implementación de los bundles.

Descriptores: Tecnología; Infecciones; Prestación de Atención de Salud; Enfermería; Cuidados Críticos. 


\section{INTRODUCTION}

At present, the concept of hospital infection is referred to as healthcare-associated infection (HAl), because this type of health problem results from possible failures in health care ${ }^{(1)}$. Healthcareassociated infections are characterized as adverse events, which are more frequent in intensive care units (ICUs). They are defined as unintended complications that result from care delivered to patients and are not related to the natural progression of the underlying disease. These events have direct consequences on patient safety and expose the fragility of the quality of healthcare services ${ }^{(2)}$.

Technological advances in the health area have considerably increased survival of critical patients, especially those who receive care in ICUs. In contrast, the severity of the underlying disease, the frequent use of antimicrobial agents, the length of stay in ICU, and the invasive procedures to which these patients are exposed are risk factors for the development of HAls ${ }^{(1)}$.

The most frequent HAls in ICUs are primary bloodstream infection (PBI), ventilator-associated pneumonia (VAP), and urinary tract infection (UTI). The main devices used in ICU that favor these infections are central venous catheter, mechanical ventilator, and urinary catheter, respectively ${ }^{(1-2)}$. As a consequence, they cause higher hospital morbidity and mortality rates and a longer hospital stay, which leads to an increase in health-related costs ${ }^{(3-5)}$.

In order to increasingly minimize the density of incidence of these infections, several strategies have been implemented. The Brazilian Health Regulatory Agency (Anvisa, as per its acronym in Portuguese), based on publications by the Institute for Healthcare Improvement $(\mathrm{IHI})$, presented some packages of measures to prevent HAls, named bundles ${ }^{(1)}$.

The concept of bundle was initially developed by $\mathrm{IHI}$, and means a package or set of measures oriented toward helping professionals who deliver health care for them to offer, in a structured manner, the best possible treatment to patients submitted to specific treatments with inherent risks ${ }^{(6)}$. It is an ordered way to improve care processes and patients' results, a synthetic and practical set of evidence-based practices. Implementing a combination of about five items of this set with safety improves patients' results by minimizing the density of incidence of HAls.

Despite the factors that work against the reduction of $\mathrm{HAI}$ incidence, implementing these bundles, obtaining sustained adherence to all the components, and putting a patient safety culture into practice made it possible to reach and keep a PBI rate equal to zero in an $\mathrm{ICU}^{(7)}$. Considering that reducing the incidence of HAls by implementing bundles is feasible and grounded in scientific evidence has led to the implementation of strategies to promote, disseminate, and teach the use of bundles.

The Brazilian Ministry of Health (MH), by means of the Support Program for the Institutional Development of the Brazilian Unified Health System (Proadi-SUS, as per its acronym in Portuguese), formulated support projects, with continued actions for the 2018-2020 triennium. Among these projects, Improving Patient Safety in Brazil on the Large Scale stands out. It establishes, among other measures, interventions to reduce the occurrence of HAls, with the specific objective of reducing the density of incidence of these infections in $50 \%$ in the ICUs that participate in the project until December 2020(1).
Regarding strategies to prevent HAls, there are documents, laws, decrees, programs, and scientific articles that aim to bring further information and provide patient safety with resources. However, this information usually can be found in abundance in several data banks, university repositories, online databases, specialized journals, institutional websites, and governmental sites, among others.

This scenario brought about the need to put together the main contents related to HAls prevention and host them in a didactic and practical way in an educational website. The development of an educational website can be classified as an innovative educational proposal that aims to update nurses' knowledge and bring theory and practice closer ${ }^{(7)}$.

Consequently, the authors considered that the development of an educational website addressing prevention of HAls in ICUs would be pertinent. Producing a compendium of the main scientific publications on prevention of adverse events and strategies that should be used to achieve this goal was feasible in the researchers'view.

\section{OBJECTIVE}

To describe the development of a website about the main HAls and the respective bundles that can be used to prevent these diseases, oriented toward the nursing work in ICUs.

\section{METHODS}

The object of the present study was the development of technological innovation (design of an educational website) by nurses, from the initial conception up to the final product, by means of methodological research on technological production and following the steps recommended by the product development process ${ }^{(8)}$. It was carried out in the context of a graduate course, professional master's modality, in the Health Technology and Innovation Research Group from August 2018 to June 2020.

Research ethical aspects were observed, in accordance with Resolution 510/2016 of the Brazilian National Health Council, given that the study involved data banks, which contain aggregated information, with no possibility of individual identification.

The development of the website occurred in four phases (Figure 1).

The description of technological innovation is shown as the motivation to develop the educational website, followed by the development phases.

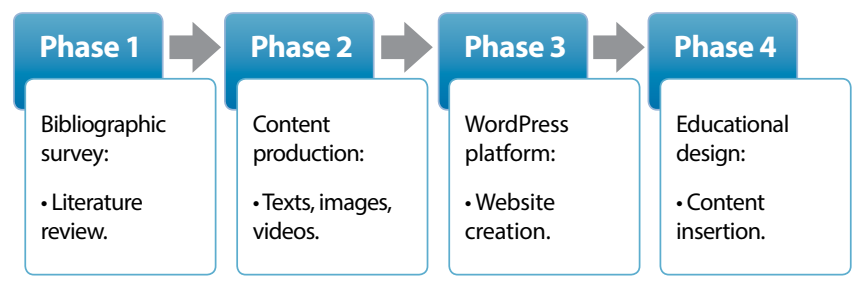

Figure 1 - Phases for designing the website

\section{On the motivation}

One of the main motivations to develop the proposed technology to contribute to the implementation of practices that reduce the density of infections in ICUs originated in the MH's sui generis project Improving Patient Safety in Brazil on the Large Scale, whose 
objective is to reduce the incidence of the main HAls (PBI, VAP, and UTI) in $50 \%$ in selected ICUs until December $2020^{(1)}$.

The authors considered that developing an educational website addressing prevention of HAls in ICUs which offered a selection of the main scientific publications and strategies to prevent these adverse events was feasible in the researchers'view. Therefore, they engaged in carrying out a literature review on the subject. Subsequently, they drafted texts, designed illustrative images, and made concise videos related to the HAls subject. Last, a website was developed, with the domain irastis.com, to make the formulated contents available.

\section{On the phases to develop the website}

\section{Phase 1: Bibliographic survey and literature review}

The bibliographic survey occurred in databases (PubMed, SciELO, and Web of Science), virtual libraries (Virtual Health Library and the Journals website of the Coordination for the Improvement of Higher Education Personnel), and documents published by Anvisa, IHI, and $\mathrm{MH}$, the institutions responsible for formulating guidelines, norms, and measures to prevent and control HAls. The descriptors "Patient care bundles"AND ("Catheter-Related Infections"OR"Pneumonia, ventilatorassociated" OR "urinary catheter") were used as search strategies.

Once this search strategy was defined, 72 articles were found, 40 of which related to PBI, 21 to VAP, and 11 to UTI. After analysis of titles and abstracts, 17 studies were eligible for the study ( 9 on PBI, 4 on VAP, and 4 on UTI). The inclusion criteria were materials published between 2015 and 2019 related to the packages of measures to prevent $\mathrm{PBI}, \mathrm{VAP}$, and UTI, caused mainly by the use of their associated devices. Publications describing studies carried out in pediatric ICUs or sectors unrelated to the ICU setting were excluded.

Among the analyzed studies, eligible to support the contents of the website, the following stood out, with the respective levels of evidence: three systematic reviews (level 1), one clinical trial (level 2), nonrandomized interventional studies (level 3), and five cohort studies (level 4), in addition to Anvisa, $\mathrm{MH}$, and IHI documents. These references are listed in the References navigation tab of the website.

\section{Phase 2: Content production: Texts, illustrative images, and videos}

The second phase consisted of writing synthetic texts based on scientific literature, designing illustrative images, and making educational videos. It also included designing the IRASTIS logotype following the standard that already existed for the Health Technology and Innovation Research Group, used in other systems and apps developed by the group. For the production and editing of the videos, several apps specific for this purpose were used: OBS Studio, Power Point, Adobe Premiere, Windows Video Editor, and Android Voice Recorder. Eight steps were followed (Chart 1).

The videos for the website irastis.com were produced by following the same sequence of steps: at the beginning of each video, the researcher presented a concise introduction on the subject to the discussed; subsequently, a five-second opening sequence was shown that referred to the concept of IRAS TIS (the combination of the acronyms for healthcare-associated infection and health technology and innovation in Portuguese); then the main content of the video (which lasted from three to five minutes) was presented; and, last, a seven-second ending sequence was inserted to conclude the video, with the logotypes of the university (Federal University of Paraná), graduate course (Healthcare Practice Graduate Course), research group (Health Technology and Innovation), and developed website (irastis.com) linked in sequence, with reference to the credits for the development of the technology.

The Android Voice Recorder tool and a lavalier microphone were used for voice recording in all videos. The first part of each video, in which the researcher presents a brief introduction, was recorded with the OBS Studio app, with a green screen for application of the chroma key effect. The portal website itself was applied as the video panel. The researcher's voice was simultaneously recorded by Android Voice Recorder. Sound mixing was carried out by using the Adobe Premiere app, and the voices in the recorder and in the original video were synchronized. The latter, which was noisier, was suppressed by Adobe Premiere. The video was then exported in the MP4 1080p configuration, in full high definition.

Chart 1 - Steps to produce and edit the videos

\begin{tabular}{|c|l|l|l|}
\hline STEP & ACTIVITIES & TOOLS & RESULTS \\
\hline 1 & $\begin{array}{l}\text { Bibliographic survey, literature review, and content } \\
\text { synthesis }\end{array}$ & $\begin{array}{l}\text { Mendeley, Acrobat Reader, and } \\
\text { Microsoft Word }\end{array}$ & Writing of concise introductory texts and contents \\
\hline 2 & $\begin{array}{l}\text { Recording of the introduction of the videos and of the } \\
\text { audio separately (concomitantly) }\end{array}$ & $\begin{array}{l}\text { OBS Studio, 1080p Logitech camera, } \\
\text { Android, and lavalier microphone }\end{array}$ & $\begin{array}{l}\text { Introductory videos, in MP4 1080p format (full high } \\
\text { definition), and introductory audios, in MP3 format }\end{array}$ \\
\hline 3 & $\begin{array}{l}\text { Synchronization of the introductory videos with their } \\
\text { respective audios and suppression of the camera audio }\end{array}$ & Adobe Premiere & $\begin{array}{l}\text { Introductory videos, in MP4 1080p format (full } \\
\text { high definition) }\end{array}$ \\
\hline 4 & Creation of the videos' opening and ending sequences & Power Point and Windows Video Editor & Two sequences (opening and ending), in MP3 format \\
\hline 5 & $\begin{array}{l}\text { Audio recording, according to the texts of the } \\
\text { contents prepared in the literature review step }\end{array}$ & $\begin{array}{l}\text { Android Voice Recorder, with lavalier } \\
\text { microphone }\end{array}$ & Audios of the contents, in MP3 format \\
\hline 6 & $\begin{array}{l}\text { Design, selection, and editing of images consonant } \\
\text { with the audios }\end{array}$ & Power Point, Freepik, and Pixabay & Illustrative images \\
\hline 7 & $\begin{array}{l}\text { Synchronization of the audios of the contents with } \\
\text { the respective illustrative images }\end{array}$ & Windows Video Editor & $\begin{array}{l}\text { Videos of the contents, in MP4 1080p format (full } \\
\text { high definition) }\end{array}$ \\
\hline 8 & $\begin{array}{l}\text { Linking of introductory videos, opening sequence, } \\
\text { videos of the contents, and final sequence; rendering }\end{array}$ & Windows Video Editor & $\begin{array}{l}\text { Seven complete videos related to the addressed } \\
\text { subjects }\end{array}$ \\
\hline
\end{tabular}


The first steps to obtain the opening and ending sequences used in all videos were designing, editing, and animating images by using Power Point version Microsoft 365. The created material was then transferred to Windows Video Editor, in which the images designed previously and the soundtrack (the instrumental track Ritmo Alegre) were added to the videos. After the editings carried out in this app, the videos were exported in the MP4 1080p format (full high definition).

The development of the main part of the videos, which contained the main content, began with the recording of the audio in the Android Voice Recorder app, based on the previously written text. The next step, carried out in Power Point, consisted of the design, editing, and animation of images and illustrations, based on the content of the recorded audio. Subsequently, the produced audio and images were transferred to Windows Video Editor. The audio was then synchronized with the images and illustrations created previously. The instrumental track Ritmo Alegre was added as the soundtrack, with a volume of $25 \%$, and, last, the edited videos were exported in the MP4 1080p format (full high definition).

In the last step of the editing of each video, the introductory video, the opening sequence, the video with the contents, and the ending sequence were inserted into Windows Video Editor. The material was rendered and exported in the MP4 1080p format. This last step was executed for all developed videos.

\section{Phase 3: Development of the website on the WordPress platform}

The WordPress platform was used by one of the researchers to develop the IRAS TIS website, with the domain "irastis.com". This platform is a free and open system for management of contents for the internet, especially oriented toward the creation of websites (sites, portals, and blogs). This system has a diversity of preestablished website models. Users can organize and reorganize contents, as well as choose the model most suitable to the project, without the need to deal with programming.

The electronic domain (electronic address www.irastis.com) was created by putting together the abbreviation referring to the research topic IRAS (the acronym for healthcare-associated infections in Portuguese) and the abbreviation for the research group name TIS (the acronym for Health Technology and Innovation in Portuguese). It was registered at UOL HOST.

The main page of the produced website had three sections: 1. header; 2 . content; 3. footer (Chart 2). After the development of the website on WordPress, it was hosted on HostGator.

\section{Phase 4: Design of the website interface and insertion of the developed contents}

The choice of the website interface was guided by the desire that the website could be easily accessed on computers, tablets, and smartphones. This process was facilitated by the WordPress platform, which has several models available to be adapted to meet the objective of the developed website.

Subsequently, previously created texts and videos were inserted into the intended pages. The videos that would be inserted into the website were first hosted on YouTube. The links (URL) of each video were then copied from YouTube and inserted into the specific WordPress page. During this process, the videos were incorporated into the website pages automatically.

\section{RESULTS}

An educational website named IRAS TIS was developed. It can be accessed by means of computers, tablets, and smartphones on the electronic address irastis.com. Its content is open to the community as a whole and can be searched by using the navigation tabs on the main menu.

To browse the website, it is necessary to have an internet connection, but login and password are not required. Figure 2 shows the main page of the produced educational website.

In the left part of the header (Figure 2, Section 1), there is the title Healthcare-associated infection, which refers to the main subject of the portal. In the upper right corner, there is the IRAS TIS logotype. The header bottom shows the website main menu, which allows users to click on navigation tabs (HOME, WHOWE ARE, HAIs IN ICU, BUNDLES, LINKS, and REFERENCES). There is also a search box, in which contents published on the website can be searched for.

HOME is the initial page, which is shown every time irastis. com is accessed. WHO WE ARE shows a concise text about the Healthcare Practice professional master's and the research group. By clicking on HAIs IN ICU, users can see three navigation tabs (PBI, VAP, and UTI), each containing a text and a video about the respective topic. The tab BUNDLES splits into three navigation tabs (PBI BUNDLE, VAP BUNDLE, and UTI BUNDLE) and, similarly to what has been made on the pages addressing the diseases, each contains a text and a video. LINKS shows a list of websites related to the subject (Anvisa's, Centers for Disease Control and Prevention's, European Center for Disease Prevention and Control's,

Chart 2 - Sections of the website irastis.com

\begin{tabular}{|c|c|c|}
\hline \multicolumn{3}{|c|}{ MAIN PAGE OF THE EDUCATIONAL PORTAL } \\
\hline \multirow{2}{*}{$\begin{array}{l}\text { SECTION 1: } \\
\text { HEADER }\end{array}$} & $\begin{array}{l}\text { - Left: title Healthcare-associated infections } \\
\text { - Upper right corner: IRAS TIS logotype }\end{array}$ & $\begin{array}{l}\text { Changes according to the } \\
\text { clicked navigation tab }\end{array}$ \\
\hline & $\begin{array}{l}\text { - Lower part: main menu, with the following navigation tabs: HOME; WHO WE ARE; IRAS IN ICU; BUNDLES; } \\
\text { LINKS; REFERENCES }\end{array}$ & Present in all accessed pages \\
\hline \multirow{2}{*}{$\begin{array}{l}\text { SECTION 2: } \\
\text { CONTENTS }\end{array}$} & - Left column: videos, texts, and hyperlinks & $\begin{array}{l}\text { Changes according to the } \\
\text { clicked navigation tab }\end{array}$ \\
\hline & - Right column: "About this website" text; several "Links"; "Search" box; number of visitors; "Comments" area & Present in all accessed pages \\
\hline $\begin{array}{l}\text { SECTION 3: } \\
\text { FOOTER }\end{array}$ & $\begin{array}{l}\text { - Left column: menu with navigation tabs (the same found on the main menu) } \\
\text { - Mid column: logotype of the graduate course and image with the combination of the IRAS TIS and YouTube } \\
\text { logotypes (both are links to the respective websites) } \\
\text { - Right column: logotype of the research group and the university (the first is a link to the research group website) }\end{array}$ & Present in all accessed pages \\
\hline
\end{tabular}


IHI's, MH's, and PROQUALIS's). REFERENCES gathers the studies used to substantiate the development of the website contents.

Below the main menu, in Section 2, left column (in HOME), there is a tutorial video that guides users on how to browse the website. This column changes according to the clicked navigation tab. On the right column, in all accessed pages, there are: the text "On this website", which contains a brief summary of the website content; several links that direct users to websites of public institutions that address the HAls subject; another search box, whose function is the same of that present on the main page (Section 1) and that allows to search contents published on the website; the number of visitors; and a "Comments" area, in which users can write comments and ask questions.

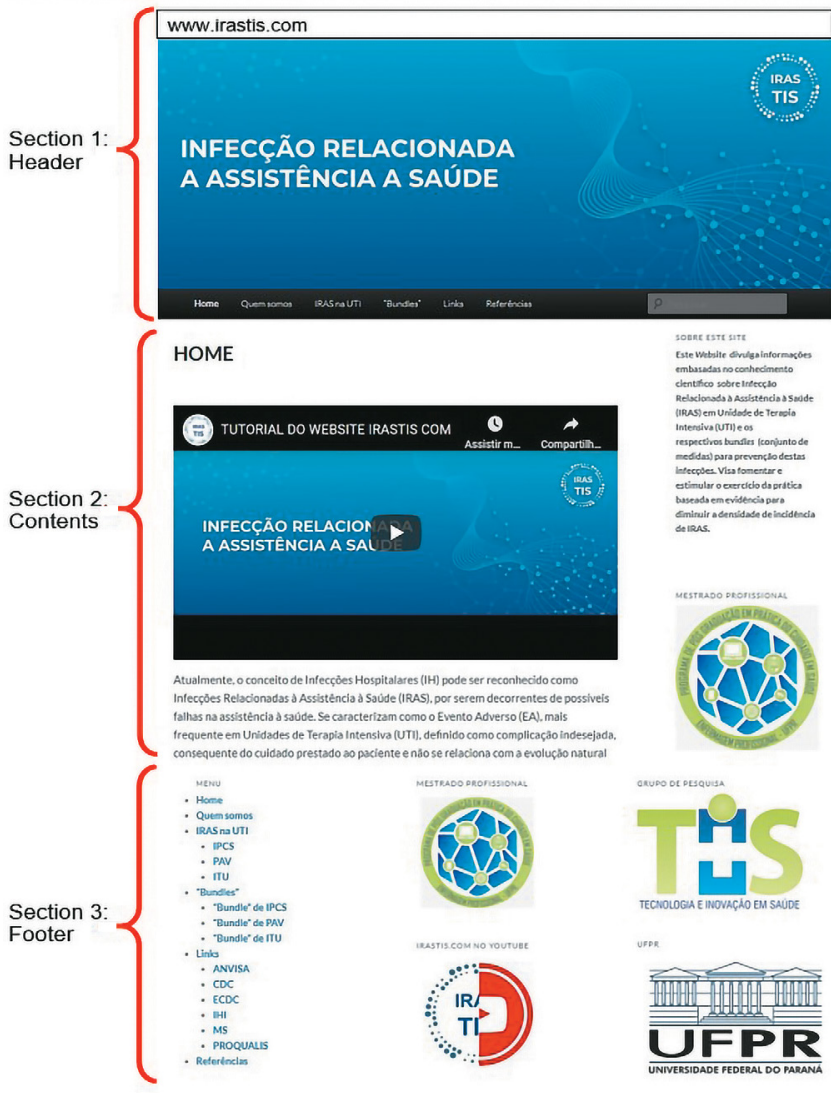

Figure 2 - Main page of the developed website

The website footer (Section 3) has a column on the left with a menu with the same navigation tabs present in the main menu, so users can have access to it when at the bottom of a page without the need to go back to the main page. The second footer column has two images: the upper is the graduate course logotype, and the lower is the combination of the IRASTIS and YouTube logotypes. Both are links to the graduate course website and the IRAS TIS YouTube channel, created exclusively to host the produced videos. The footer right column shows the logotypes of the research group and of the Federal University of Paraná, which are also links to their websites.

\section{DISCUSSION}

In the HAls in ICU context, the amount of contents accessible via specialized scientific journals, governmental agencies, university repositories, laws, decrees, and programs, among others, is immeasurable. All these contents aim to disseminate the magnitude of this problem and provide theoretical resources with scientific grounds, to improve the HAls scenario. Consequently, a synthetic compendium of the information contained in these diverse means of dissemination of scientific contents seemed appropriate.

In the health area, websites have been widely used as tools for communication and information dissemination. They are an efficient resource to share scientific knowledge and have proved an agile means to inform, share, and exchange experiences, offering the possibility of being a search environment for undergraduate students and professionals who must undergo continuing education. They can be used to develop new thoughts, collect health surveillance data, and share views and perceptions regarding individual and collective health issues ${ }^{(9)}$.

The results of an overview of systematic reviews carried out by Canadian researchers and published by the Journal of Medical Internet Research entitled Impact of Information and Communication Technologies on Nursing Care: Results of an Overview of Systematic Reviews showed that information and communications technologies are boosting the continuous improvement of the quality of health care delivered by nurses. The use of information and communications technologies by this category of professionals can impact their practice, changing the ways they plan, implement, record, and review positive modifications in the manner nurses develop their activities ${ }^{(10)}$.

Virtual environments, such as websites, make it possible to integrate different contents related to the same subject, showing all of them at the same time, complementing them and offering users the possibility of making the most of each material, which favors searches. The frequent use of these tools in the healthcare field has been considered an important facilitator of health education ${ }^{(7)}$.

Technological mediation in educational activities has strengthened the process of information dissemination inherent in HAls prevention. There are expectations that scientific advances can improve the quality of the delivered care, increasingly minimizing adverse events resulting from hospital infections. In this scenario, studies on technological innovation are essential to meet the demands that emerge from changes in society.

\section{Study limitations}

The fact that nursing professionals do not fully master the resources used in making and editing of videos, website development, and educational design can be considered a limitation. However, over the development of the website, it was found that the design of innovative technologies by nursing professionals is feasible in the current context, in which information and communications technologies are increasingly more present.

\section{Contributions to the nursing, health, or public policy areas}

The educational website IRAS TIS, with the irastis.com domain, provides information about the main HAls in ICU and their respective bundles, defined as sets of measures used to prevent these infections. It has the potential to contribute to reducing the occurrence of this health problem if the strategies shown are implemented. It provides patients with benefits, favoring their safety; it helps professionals, because it allows them to carry out 
evidence-based practice; and it is good for society in general, for reducing health-related costs.

In October 2020, three months after being launched, the website had registered around two thousand accesses, without having been promoted on social media. This fact suggests that the subject is pertinent, and reinforces the professionals' need for frequent updating. The website content will be updated systematically by master's and PhD students at the Health Technology and Innovation research group at the Federal University of Paraná.

\section{FINAL CONSIDERATIONS}

Several efforts have been made to promote and disseminate scientific evidence results in the HAls context. In face of the innovations resulting from information and communications technologies, together with the increasingly more frequent search for information by means of electronic media, the development of an educational website about HAls prevention proved pertinent.

The experience of the development of a website by a group of professionals with no training in the informatics area showed that the use of digital technologies to meet many demands in the health area is possible. Therefore, it is important that nurses develop skills in the informatics area (which has increasingly friendlier interfaces) to combine clinical practice and research and educational activities, which are usually carried out in healthcare settings, with technological innovation creation oriented toward health and nursing.

\section{REFERENCES}

1. Ministério da Saúde (BR). Projeto Melhorando a Segurança do Paciente em Larga Escala No Brasil [Internet]. Brasília. 2018 [cited 2020 Mar 9]. Available from: http://www.saude.gov.br/saude-de-a-z/seguranca-do-paciente

2. Rodrigues AN, Fragoso LVEC, Beserra FM, Ramos IC. Determining impacts and factors in ventilator-associated pneumonia bundle TT. Rev Bras Enferm. 2016;69(6):1108-14. https://doi.org/10.1590/0034-7167-2016-0253

3. Azar J, Kelley K, Dunscomb J, Perkins A, Wang Y, Beeler C, et al. Using the agile implementation model to reduce central line-associated bloodstream infections. Am J Infect Control. 2019;47(1):33-7. https://doi.org/10.1016/j.ajic.2018.07.008

4. Okgün AA, Demir KF, Uyar M. Prevention of ventilator-associated pneumonia: use of the care bundle approach. Am J Infect Control. 2016;44(10):e173-6. https://doi.org/10.1016/j.ajic.2016.04.237

5. Al-Abdely HM, Khidir MY, Rosenthal VD, Orellano PW, ALazhary M, Kaid E, et al. Impact of the International Nosocomial Infection Control Consortium (INICC)'s multidimensional approach on rates of ventilator-associated pneumonia in intensive care units in 22 hospitals of 14 cities of the Kingdom of Saudi Arabia. J Infect Public Health. 2018;11(5):677-84. https://doi.org/10.1016/j.jiph.2018.06.002

6. Hakko E, Guvenc S, Karaman I, Cakmak A, Erdem T, Cakmakci M. Long-term sustainability of zero central-line associated bloodstream infections is possible with high compliance with care bundle elements. East Mediterr Health J. 2015;21(4):293-8. https://doi. org/10.26719/2015.21.4.293

7. Barros FRB, Amâncio CV, Ferreira MDDS. Desenvolvimento de um website educacional para o ensino do processo de enfermagem em cardiologia. Enferm Foco. 2017;8(2):67-71. https://doi.org/10.21675/2357-707X.2017.v8.n2.1033

8. Salgado EG, Salomon VAP, Mello CHP, Fass FDM, Xavier AF. Modelos de referência para desenvolvimento de produtos: classificação, análise e sugestões para pesquisas futuras. Rev Prod [Internet]. 2010 [cited 2019 Dec 8];10(4). Available from: https://producaoonline.org.br/rpo/ article/view/520

9. Sander A, Lobo M. O uso das TICs como ferramenta de ensino-aprendizagem no Ensino Superior. Cad Geogr. 2015;25(44):16-26. https://doi. org/10.5752/p.2318-2962.2015v25n.44p.16

10. Rouleau G, Gagnon MP, Côté J, Payne GJ, Hudson E, Dubois CA. Impact of information and communication technologies on nursing care: results of an overview of systematic reviews. J Med Internet Res. 2017;19(4):e122. https://doi.org/10.2196/jmir.6686 